\title{
Optimization Formulation of Antioxidant Cream Vitamin E ( $\alpha$-tocopherol acetate) with Virgin Coconut Oil (VCO)
}

\author{
Dian Ermawati *, Uswatun Chasanah and Dwi Dwi \\ Departement of Pharmacy, Faculty of Health Science, University of Muhammadiyah Malang, Indonesia \\ Jalan. Bendungan Sutami 188A, Kota Malang, Jawa Timur, 65145 \\ *Corresponding author: dianerma@umm.ac.id
}

\begin{abstract}
Background: Vitamin E is an antioxidant that can be formulated in a cream. VCO can be used as the oil phase in cream and can also function as an antioxidant, moisturizer and emollient. Objective: The purpose of this study is to determine the effect of concentration level VCO in formula 1 (3\%), formula 2 (6\%), formula 3 (9\%), and formula 4 (12\%) antioxidant vitamin E vanishing cream base for physical characteristics, the chemical characteristics $(\mathrm{pH})$, and the stability test (freeze thaw), and determining levels of VCO which can give optimum results of characteristics. Method: This study used experimental method. Result: Results of the homogeneity test cream show a homogeneous composition and is not visible to the graininess. The results showed that the $\mathrm{pH}$ value range between 6.553-7.146, the viscosity 12.000-26.000 cPs, and globule size distribution 0.2733-0.3220 mm, the results are analyzed using Oneway ANOVA showed significant differences. For the measurement of $\mathrm{pH}$ after freeze thaw stability test ranges 5.604-6.428 and the dispersion power 0.0792-0.1243 g/cm no showed significant difference. Conclusion: Variation VCO in the formula 1, 2, 3, and 4 effects on the physical characteristics, chemical, stability test and VCO with concentration $12 \%$ give the best formula for optimal results.
\end{abstract}

Keyword: Vitamin E, Virgin Coconut Oil

\section{INTRODUCTION}

Premature aging is closely related to free radicals. To minimize bad effect of free radicals, it can use preparations containing antioxidants. One of the antioxidants that can be used is vitamin E. Antioxidants can be formulated in oral and topical dosage forms. Cream is one form of topical preparations. Cream there are phases of water and oil. One of the oils that can be used as cream base is Virgin Coconut Oil (VCO), because VCO also can function as antioxidant, moisturizer, and emollient. According to Rindengan and Novarianto (2004), one of the natural skin moisturizers is VCO because it is able to prevent tissue damage and provide protection against the skin. In addition, it also has a very high antioxidant and moisturizers which antioxidants function to prevent premature aging and maintain the vitality of the body (Nilamsari, 2006). Therefore, the authors are interested to use VCO in oil phase in cream preparations. 


\section{METHOD}

The purpose of this study was to determine the effect of VCO concentration of $3 \%, 6 \%$, $9 \%$, and $12 \%$ on the basis of vanishing cream on vitamin $\mathrm{E}$ antioxidant cream preparations to physical characteristics (organoleptis, homogeneity, viscosity, spreadibility, and globul size distribution), Chemical characteristics $(\mathrm{pH})$, and stability test (freeze thaw). It is also to determine the level of VCO that can provide optimal results on the above characteristics. In this research, the preparation was prepared with five levels of formula. There are formula $0,1,2,3,4$ and 5 with VCO concentration respectively (0\%), (3\%) (6\%) $(9 \%)(12 \%)$ (table 1)

Table 1 Formulation of vanishing cream using VCO

\begin{tabular}{llllll}
\hline Ingredients & F0 & F1 & F2 & F3 & F4 \\
\hline Vitamin E & $3 \%$ & $3 \%$ & $3 \%$ & $3 \%$ & $3 \%$ \\
VCO & $0 \%$ & $3 \%$ & $6 \%$ & $9 \%$ & $12 \%$ \\
Stearic acid & $15 \%$ & $15 \%$ & $15 \%$ & $15 \%$ & $15 \%$ \\
Cera alba & $2 \%$ & $2 \%$ & $2 \%$ & $2 \%$ & $2 \%$ \\
Petroleum & $4 \%$ & $4 \%$ & $4 \%$ & $4 \%$ & $4 \%$ \\
Trietanolamin & $1 \%$ & $1 \%$ & $1 \%$ & $1 \%$ & $1 \%$ \\
Propilenglycol & $8 \%$ & $8 \%$ & $8 \%$ & $8 \%$ & $8 \%$ \\
Methylparaben & $0,1 \%$ & $0,1 \%$ & $0,1 \%$ & $0,1 \%$ & $0,1 \%$ \\
Propyl paraben & $0,08 \%$ & $0,08 \%$ & $0,08 \%$ & $0,08 \%$ & $0,08 \%$ \\
\hline Aquadest & $66,82 \%$ & $63,82 \%$ & $60,82 \%$ & $57,82 \%$ & $54,82 \%$ \\
\hline
\end{tabular}

The evaluation of the preparation includes the type of emulsion, physical characteristics (organoleptic, homogeneity, viscosity, dispersion, and globule size distribution), chemical characteristics $(\mathrm{pH})$, and freeze thaw.

\section{RESULT AND DISCUSSION}

Emulsion type test using dilution method using aquadest and staining method using methylene blue to ensure that the cream preparation including emulsion type $\mathrm{m} \mathrm{O} / \mathrm{W}$. the four formulas showing the vanishing cream vitamin E preparation with the VCO oil phase is belong to the $\mathrm{O} / \mathrm{W}$ cream type, which is a uniformly spread in blue color and the cream is easily diluted with aquadest.

On organoleptic examination, it is found that all cream preparations are white and have a soft texture. If it is observed from the smell of the cream of the formula 0 formula is odorless because of the VCO content ( $0 \%)$, whereas in the formula 1, 2, 3, and 4 already added VCO with various levels have a distinctive odor of VCO.

Based on the results of homogeneity examination vanishing cream vitamin $\mathrm{E}$ with VCO oil phase showed a homogeneous texture and no visible spots. The result of $\mathrm{pH}$ examination showed the mean $\mathrm{pH}$ of formula $0(7,146 \pm 0,207)$, formula $1(6,946 \pm 0,179)$, formula $2(6,757$ $\pm 0,139)$, formula $3(6,644 \pm 0,157)$, and formula $4(6,553 \pm 0,201)$. Based on these results means that $\mathrm{pH}$ of vanishing cream vitamin $\mathrm{E}$ with $\mathrm{VCO}$ oil phase meets the requirements of $\mathrm{pH}$ SNI 16-4399-1996 which is ranged from 4.5-8,0 (DSN, 1996). But if it refers to a skin pH of 4.56.5 , only formula 4 meets skin $\mathrm{pH}$ requirements. To know the effect of the increase of $\mathrm{VCO}$ 
content used in the preparation was done by One-way ANOVA statistical analysis. The result $\mathrm{p}$ $(0,014)<\alpha(0,05)$ so there is significant difference. To know the significance of each formula difference HSD test was done so that the result between formula 0 and 3 there was significant difference $(\alpha=0,040)$ and formula 0 and 4 there was significant difference $(\alpha=0,015)$.(Fig 1$)$

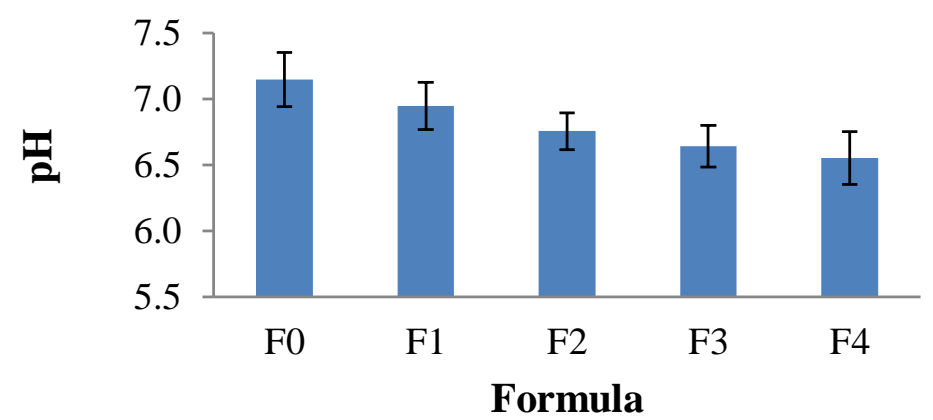

Figure 1 pH value of vanishing cream contains VCO

The results of the measurements of the viscosity of each formula show the mean \pm SD of formula $0(12,000 \pm 2000.00 \mathrm{cPs})$, formula $1(15.667 \pm 4041.45 \mathrm{cPs})$, formula $2(19.667 \pm$ $577.35 \mathrm{cPs})$, formula $3(22.667 \pm 577,35 \mathrm{cPs})$, and formula $4(26,000 \pm 2000,00 \mathrm{cPs})$. The value is included in the range of quality requirements of cream preparations ranging from 2,000-50,000 cPs (DSN, 1996). To determine the effect of increased levels of VCO used in the preparation is done One-Way ANOVA statistical analysis with a degree of trust $\alpha=0.05$, obtained Results $p$ $(0,000)<\alpha(0.05)$ which means there is a significant difference. In order to know the significance of each formula difference HSD test was done so that the result between formula 0 and 2 has significant differences $(\alpha=0,012)$, formula 0 and 3 there are significant differences $(\alpha=0,001)$, formula 0 and 4 there is significant difference $(\alpha=0,000)$, Formula 1 and 3 there were significant differences $(\alpha=0,022)$, formula 1 and 4 there were significant differences $(\alpha=$ $0,002)$, and formula 2 and 4 were significant differences $(\alpha=0,038)$ (Fig 2)



Figure 2 Viscosity value of vanishing cream contain VCO

Based on spread ability test in this research each formula show mean \pm SD formula 0 $(0,1243 \pm 0,049 \mathrm{~g} / \mathrm{cm})$, formula $1(0,1190 \pm 0,011 \mathrm{~g} / \mathrm{cm})$, formula $2(0,1016 \pm 0,019 \mathrm{G} / \mathrm{cm})$, formula $3(0.0905 \pm 0.023 \mathrm{~g} / \mathrm{cm})$, and formula $4(0.0792 \pm 0.026 \mathrm{~g} / \mathrm{cm})$. To determine the effect 
of the increase of VCO content used in the preparation, One-Way ANOVA statistical analysis with degree of trust $\alpha=0,05$, the result $p(0,334)>\alpha(0,05)$ so there is no significant difference.

The diameter measurement of the average globule, it showed that the average \pm SD size of vanishing cream vitamin E with the oil phase of VCO formula $0(0.2733 \pm 0.0196 \mathrm{~mm})$, formula $1(0.2780 \pm 0.0106 \mathrm{~mm})$, formula $2(0.3017 \pm 0.0136 \mathrm{~mm})$, formula $3(0.3197 \pm 0.0180$ $\mathrm{mm})$, and the formula $4(0.3220 \pm 0.0193 \mathrm{~mm})$. Based on these results it can be concluded that the size of globules of vanishing cream vitamin E with the VCO oil phase does not meet the diameter size requirement in accordance with the literature ie the drip dispersed sizing range of a physically stable emulsion between 0.001 to $0.1 \mathrm{~mm}$, (Gennaro, 1990). To know the effect of the increase of VCO content used in the preparation was done statistical analysis One-way ANOVA with degree of trust $\alpha=0,05$, got result $p(0,012)<\alpha(0,05)$ so there is a significant difference. To know the significance of each difference, the formula was tested by HSD test to obtain the result between formula 0 and 4terdapat significant difference $(\alpha=0,031)$ and formula 1 and 4terdapat significant difference $(\alpha=0,041)$.

The result of observation of vanishing cream vitamin E preparation with VCO oil phase on stability test of freeze thaw showed that cream preparation has good stability, no visible phase separation. However, the $\mathrm{pH}$ of the preparation after the freeze thaw stability test was decreased compared to the initial $\mathrm{pH}$. The $\mathrm{pH}$ measurement results after the freeze thaw stability test of each formula showed the mean \pm SD of formula $(6.428 \pm 0.229)$, formula $1(6,138 \pm 0.401)$, formula $25,869 \pm 0.534)$, formula $3(5,716 \pm 0.581)$, and formula $4(5,604 \pm 0.542)$. But the results still meet the requirements of pH SNI 16-4399-1996 which ranges between 4.5-8.0 (DSN, 1996) and skin $\mathrm{pH} 4.5-6,5$.

\section{CONCLUSION}

It can be concluded that the preparation of vanishing cream of vitamin $\mathrm{E}$ made with variation of VCO content of formula $1(3 \%)$, formula $2(6 \%)$, formula $3(9 \%)$, and formula 4 $(12 \%)$ has significant difference at $\mathrm{pH}$, viscosity And globule size distribution, but it has no significant difference in $\mathrm{pH}$ after freeze thaw stability test and spreading effect as well as effect on physical characteristic that causes denser density of texture, increased viscosity, decrease of spread ability, and increase globule size distribution, Decrease in $\mathrm{pH}$, and on the stability test no phase separation and decreased $\mathrm{pH}$ of the preparation after freeze thaw stability test compared to initial $\mathrm{pH}$ of the preparation.

\section{REFERENCES}

Ames, B.N., Shigenaga, M.K., \& Hagen, T.M. (1993). Oxidants, antioxidants, and the generative diseases of aging. Proc. Natl. Acad. Sci, 90, 7915-22.

Aghel, N., Moghimipour, E., \& Ameri, A. (2007). Characterization of an Anti-dermatophyte cream from zataria multiflora boiss. Iranian Journal on Pharmaceutical Sciences Spring, 3(2), 77- 84.

Agustin, R., et al. (2013). Formulasi krim tabir surya dari kombinasi etil p- metoksisinamat dengan katekin. Prosiding seminar nasional perkembangan terkini sains farmasi dan klinik III.Fakultas Farmasi Universitas Andalas.

Aryani, R. (2015). Formulasi dan uji stabilitas krim kombinasi alfa tokoferol asetat dan etil vitamin c sebagai pelembab kulit. Jurnal Kesehatan Bakti Tunas Husada, 14(1). 
Aulton, M. E. (2003). Pharmaceutics the science of dosage form design (2nd Ed). ELBS Funded by British Government

Badarinath, A., Rao, K., Chetty, C.S., Ramkanth, S., Rajan, T., \& Gnanaprakash, K. (2010). A review on in-vitro antioxidant methods: comparisons, correlations, and considerations. International Journal of PharmTech Research, 1276-1285.

Barry, B.W. (1983). Dermatologi formulations. New York and Basel: Marcel Dekker Inc.

Baumann, L. (2002). Antioxidants. in: cosmetic dermatology: principles and practice. Hongkong: McGraw-Hill.

Bickers, D.R., Parrish, J.A., \& Lowe, N.J. (1991). National Institutes of Health Summary of the Consensus Development Conference on Sunlight, Ultraviolet Radiation and the Skin. J Am Acad Dermatol, 24, 608- 612.

Biradar, S.V., Dhumal, R.S., \& Paradkar, A. (2009). Rheological investigation of selfemulsification process. J. Pharm. Pharmaceut. Sci, 1(12), 17-31.

Lucida, H., Salman, \& Hervian, M.S. (2008). Uji daya peningkat penetrasi virgin coconut oil (VCO) dalam basis krim. Jurnal Sains dan Teknologi Farmasi, 13(1), 23- 30.

Masaki, H. (2010). Role of antioxidants in the skin: Anti-aging effects. J Derm Sci, 58, 85-90.

Pudyastuti, B., Marchaban, \& Kuswahyuning, R. (2015). Pengaruh konsentrasi xanthan gum terhadap stabilitas fisik krim virgin coconut oil (VCO). Jurnal Farmasi Sains dan Komunitas, 12(1).

Ugandar, R.E., \& Deivi, K.S. (2013). Formulation and evaluation of natural palm oil based vanishing cream. IJPSR, 4(9), 3375-3380. 